\title{
Stability Indicating HPLC Method for Simultaneous Determination of Several Angiotensin-II-Receptor Antagonists in Their Dosage Forms
}

\author{
Abdullah A Elshanawane ${ }^{1}$, Lobna M Abdelaziz² and Hani M Hafez ${ }^{3 *}$
}

${ }^{1}$ Professor of Medicinal Chemistry, Department of Medicinal Chemistry, Faculty of Pharmacy, Zagazig University, Egypt

${ }^{2}$ Assistant Professor of Medicinal Chemistry, Department of Medicinal Chemistry, Faculty of Pharmacy, Zagazig University, Egypt

${ }^{3}$ Bachelor Degree of Pharmaceutical Science, Zagazig University, Quality Control Department, EIPICO, Egypt

\begin{abstract}
A stability-indicating reversed-phase liquid chromatographic (RP-HPLC) method has been established for simultaneous determination of four angiotensin-II-receptor antagonists (Losartan potassium, Valsartan, Telmisartan and Irbesartan) in the presence of the degradation products generated in studies of forced decomposition. All drug substances were subjected to drastic condition of stress studies involving hydrolysis by acid and base, thermal decomposition by heat at $70^{\circ} \mathrm{C}$, oxidation by hydrogen peroxide and photo degradation. Losartan potassium and Valsartan were degraded acidic conditions. Irbesartan was degraded basic conditions. Telmisartan showed good stability against all stress conditions. Successful separation of the drugs from the degradation products was achieved on ACE C18 column $(250 \mathrm{~mm} \times 4.6 \mathrm{~mm}, 5 \mu \mathrm{m})$ with $65: 35 \%(\mathrm{v} / \mathrm{v})$ potassium dihydrogen phosphate $(0.025 \mathrm{M}, \mathrm{pH}$ 6.0): acetonitrile as a mobile phase at flow rate $1.5 \mathrm{ml} / \mathrm{min}$ with UV detection at $220 \mathrm{~nm}$. The proposed method was validated in terms of linearity, accuracy, precision and limits of detection and quantitation. Statistical analysis proved the method enabled reproducible and selective quantification of these drugs as the bulk drug and in pharmaceutical dosage forms. Because the method effectively separates the drugs from their degradation products, it can be used as stability-indicating.
\end{abstract}

Keywords: Stability indicating HPLC; Losartan potassium; Irbesartan; Valsartan; Telmisartan

\section{Introduction}

Angiotensin antagonists are the first major innovation in essential hypertension management as a first-line treatment. Angiotensin II receptor antagonists (ARA II) have been developed to specifically and selectively block the AT1 receptor of the rennin angiotensin system by displacing angiotensin II from it [1]. Losartan potassium, Telmisartan, Irbesartan and Valsartan are highly selective, non-peptide angiotensinII receptor antagonists (ARA-II). They are effective agents for the treatment of hypertension and heart failure either alone or together with diuretics [2].

Information on the stability of the drug substance is an integral part of the systematic approach to stability evaluation. Stress testing (or forced degradation studies) is a critical component of the drug development process [3]. The ICH guideline indicates that stress testing is designed to help "determine the intrinsic stability of the molecule by establishing degradation pathways in order to identify the likely degradation products and to validate the stability indicating power of the analytical procedures used [4]. Stress testing also is becoming increasingly important in testing new molecules. Methods developed by stress testing and the stability information gained from those methods can have a significant effect on the actual compound selected for development [3]. Literature review revealed that several methods have been reported for analysis of the drug in pharmaceutical formulation alone or with other drugs in combination. USP described a HPLC method for assay and impurities of Losartan potassium, Valsartan and their impurities B, C (RP-HPLC), Valsartan impurity A (normal phase HPLC) and Irbesartan (ion pair HPLC), ion pair HPLC for Telmisartan [5]. BP described a potentiometric titration for assay of Losartan potassium, Irbesartan, Telmisartan and Valsartan. For impurities BP used a gradient RP-HPLC for Losartan potassium and ion pair HPLC for Telmisartan [6]. Some methods have been published for simultaneous determination of studied ARA-II-drugs including
Spectrophotometry [7], HPLC-DAD [2], HPLC with fluorimetric detection [1] and capillary zone electrophoresis $[8,9]$. Some stability studies were reported for Losartan [10-13], Irbesartan [14,15], Valsartan [16-18] and Telmisartan [19]. But no published method depends on optimum stress test conditions [20] and it is the first stability study which comprises the four ARA-II compounds together. So, our scope is achieving a stress testing study of ARA-II drugs including development of a powerful stability indicating method. New study depends on previous study has been established to reach the optimum stress conditions in drug development process and time points for a detailed study (solid-state stress). Developed stability indicating method is accurate, sensitive, rapid and simple. The developed method was validated according to (ICH) guidelines with respect to specificity, linearity, limit of detection, limit of quantification, accuracy, precision and robustness [21]. The method is proved to be robust with respect to change in flow rate, $\mathrm{pH}$, organic phase composition and column temperature. It can be applied in majority of companies in the world.

Losartan potassium is 2-butyl-4-chloro-1-[[2'-(1H-tetrazol-5yl)[1,1'-biphenyl]-4-yl]methyl]-1H-imidazole-5-methanol mono potassium salt, is the first member of a new class of non-peptide angiotensin II receptor antagonist. Irbesartan is 2-butyl-3-[p- $(\mathrm{o}-1 \mathrm{H}-$

*Corresponding author: Hani M. Hafez, Bachelor Degree of Pharmaceutical Science, Zagazig University, Zagazig, Quality Control Department, EIPICO, 10th Ramadan, Egypt, Tel: 020113231458; E-mail: hanyhaf_1982@yahoo.com

Received July 15, 2012; Accepted October 06, 2012; Published October 08 2012

Citation: Elshanawane AA, Abdelaziz LM, Hafez HM (2012) Stability Indicating HPLC Method for Simultaneous Determination of Several Angiotensin-IIReceptor Antagonists in Their Dosage Forms. Pharmaceut Anal Acta 3:175. doi:10.4172/2153-2435.1000175

Copyright: (c) 2012 Elshanawane AA, et al. This is an open-access article distributed under the terms of the Creative Commons Attribution License, which permits unrestricted use, distribution, and reproduction in any medium, provided the original author and source are credited. 
tetrazol-5-ylphenyl) benzyl]-1, 3-diazaspiro [4.4] non-1-en-4-one. It is an orally active specific angiotensin II receptor antagonist used, as a hypotensive agent does not require biotransformation into an active form. Valsartan is N-(1-oxopentyl)-N-[[2-(1H-tetrazol-5-yl) [1, 1-biphenyl]-4-yl] methyl]-l-valine. Valsartan is a potent, highly selective, and orally active antagonist at the angiotensin II AT1- receptor. Telmisartan is 4-((2-n-propyl-4-methyl-6-(1-methylbenzimidazol-2yl)-benzimidazol-1-yl) methyl) biphenyl-2- Carboxylic acid (Figure 1).

\section{Experimental}

\section{Instrumentation}

Balance: KERN model 870-13, Instrument Kern Balance, Supplied from Kern, Germany

High performance liquid chromatography: Consisting of instrumental

a. AGILENT 1200 Quaternary pump.

b. AGILENT 1200 Diode Array detector (DAD).

c. AGILENT 1200 Auto sampler (injector).

d. Column: ACE column $(250 \times 4.6) \mathrm{mm}$ particle size $5 \mu$ Supplied from ACE.

e. The system equipped by Agilent chemistation PC program.

pH meter: Metrohm model $713 \mathrm{pH}$ meter, Supplied from Metrohm, Switzerland.

Stirrer: Heiedolph model MR 3002 S, Supplied from Heiedolph, Germany.

\section{Chemicals and reagents}

All reagents are analytical or HPLC grade. Potassium dihydrogen phosphate, orthophosphoric acid and sodium hydroxide $(\mathrm{NaOH})$ were supplied by (Merck, Darmstadt, and Germany), acetonitrile and methanol (HPLC grade) were supplied by (Fischer scientific, U.K.) and distilled water.

(Note: The water used in all the experiments was obtained from Milli-RO and Milli-Q systems (Millipore, Bedford, MA).

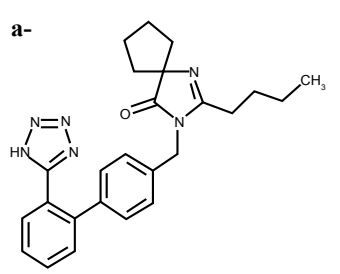

c-

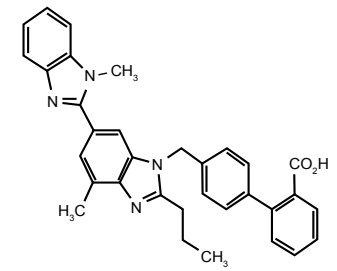

b-
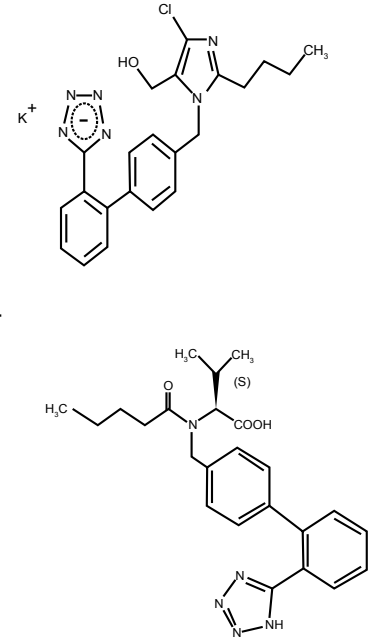

Figure 1: The structures of a- Irbesartan b- Losartan potassium c- Telmisartan d- Valsartan.
Irbesartan, Losartan potassium, Telmisartan and Valsartan working standard powders were kindly supplied by Egyptian international pharmaceutical industries company (EIPICO) (10 ${ }^{\text {th }}$ Ramadan, Egypt) and they were used without further purification.

\section{Pharmaceutical preparation}

$X$-tension tablets October pharma/EPCP (Egypt) contain (150 mg Irbesartan per tablet) B.NO: E0070211. LosarMepha tablets Medical union pharmaceuticals (Egypt) contain (50 mg Losartan potassium per tablet) B.NO:02862. Micardis tablets Boehringer Ingelheim (Germany) contain (80 mg Telmisartan per tablet) B.NO:104643. Disartan capsules Global Napi Pharmaceuticals (Egypt) contain (80 mg Valsartan per capsule) B.NO: 915003.

\section{Chromatographic condition}

Mobile phase: a mixture of $65 \%$ potassium dihydrogen phosphate buffer (0.025M, pH=6.0):35\% acetonitrile (an isocratic technique).

Column: ACE RP-C18 supplied from ACE.

Detector was set at $220 \mathrm{~nm}$.

Flow rate; $1.5 \mathrm{ml} / \mathrm{min}$.

Column temperature: $40^{\circ} \mathrm{C}$.

Injection volume: $50 \mu \mathrm{l}$

\section{Stock standard solutions}

Stock standard solutions containing $(1.5,0.5,0.8,0.8 \mathrm{mg} / \mathrm{ml})$ of Irbesartan, Losartan potassium, Telmisartan and Valsartan were prepared by dissolving $(150,50,80,80 \mathrm{mg})$ of them in methanol in $100 \mathrm{ml}$ volumetric flask respectively. Solutions were sonicated for 15 minutes and the final volume of solutions was made up to $100 \mathrm{ml}$ with methanol to get stock standard solutions.

\section{Preparation of calibration plot (working standard solutions)}

To construct calibration plots, The stock standard solutions were diluted with the mobile phase (freshly prepared) to prepare working standard solutions in the concentration ranges (30-180,10-60,16-96, 16-96 $\mu \mathrm{l} / \mathrm{ml}$ ) for Irbesartan, Losartan potassium, Telmisartan, Valsartan respectively. Each solution $(\mathrm{n}=5)$ was injected in triplicate and analyzed under the mentioned conditions above. Linear relationships were obtained when average drug standard peak area were plotted against the corresponding concentrations for each drug. Regression equation was computed.

\section{Sample preparation}

A composite of ten X-tension tablets, Losar Mepha tablets, Disartan capsules and Micardis tablets were prepared by grinding each type of tablets separately to a fine, uniform size powder, triturated using mortar and pestle. After calculating the average tablet weight, amounts of powder equivalent to 150, 50, 80 and $80 \mathrm{mg}$ for Irbesartan, Losartan potassium, Telmisartan, and Valsartan respectively were accurately weighed and transferred separately of each type of tablets to $100 \mathrm{ml}$ volumetric flasks respectively then complete with methanol up to 100 $\mathrm{ml}$. The solutions were sonicated for $15 \mathrm{~min}$ and the solutions were then filtered through $0.45 \mu \mathrm{m}$ Nylon membrane filters (Millipore, Milford, MA, USA). Aliquots of appropriate volume $(10 \mathrm{ml})$ were transferred to $100 \mathrm{ml}$ calibrated flasks and diluted to volume with mobile phase to obtain the mentioned concentration above. The diluted solutions were analyzed under optimized chromatographic conditions and chromatogram is showed in Figure 2. 


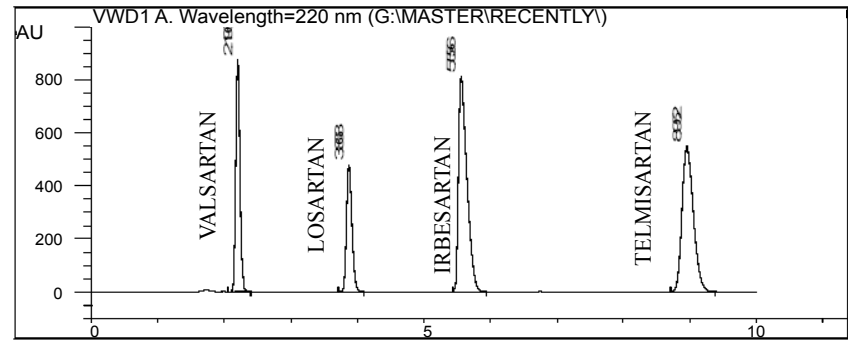

Figure 2: HPLC chromatogram of Valsartan , Losartan potassium, Irbesartan and Telmisartan respectively on ACE C-18 $(25 \mathrm{~cm})$ Column and mobile phase consisted of $(A)$ acetonitrile and $(B)$ phosphate buffer $\mathrm{pH}=6.0$ in ratio $35: 65 \%$.

\section{Forced degradation of Irbesartan, Losartan potassium, Telmisartan, and Valsartan}

To determine the proposed method as a stability-indicating method, Irbesartan, Losartan potassium, Telmisartan, and Valsartan respectively bulk powders were stressed under different conditions in forced degradation studies.

Acidic and alkaline degradation: Hydrochloric acid $(\mathrm{HCl})(1 \mathrm{M}$, $10 \mathrm{ml})$ and sodium hydroxide $(\mathrm{NaOH})(1 \mathrm{M}, 10 \mathrm{ml})$ were separately added to $10 \mathrm{ml}$ methanolic stock solutions of Irbesartan, Losartan potassium, Telmisartan, and Valsartan respectively. These mixtures were separately heated at $70^{\circ} \mathrm{C}$ for 14 days in the dark (to exclude the possible degradative effect of light). The solutions ( $1 \mathrm{ml})$ were then transferred to $10 \mathrm{ml}$ volumetric flasks, neutralized by addition of 1 $\mathrm{M} \mathrm{NaoH}$ or $1 \mathrm{M} \mathrm{HCl}$, and diluted to final volume with mobile phase $[4,20]$.

Oxidation: Hydrogen peroxide $\left(\mathrm{H}_{2} \mathrm{O}_{2} ; 3 \%, \mathrm{v} / \mathrm{v}, 10 \mathrm{ml}\right)$ was added to $10 \mathrm{ml}$ methanolic stock solutions of Irbesartan, Losartan potassium, Telmisartan, and Valsartan respectively. These solutions were separately set aside for 7 days at ambient temperature in the dark. The solutions $(1 \mathrm{ml})$ obtained were then transferred to $10 \mathrm{ml}$ volumetric flasks and diluted to final volume with mobile phase $[4,20]$.

Neutral degradation (Thermal degradation): Methanolic stock solutions of Irbesartan, Losartan potassium, Telmisartan, and Valsartan respectively were heated at $70^{\circ} \mathrm{C}$ for 14 days in the dark to study the effect of thermal stress. Also the experiment was performed on solidstate samples which could be stressed under previous condition and then diluted with a known amount of mobile phase. The experiment was performed in the dark to exclude the possible degradative effect of light. The solutions $(1 \mathrm{ml})$ obtained were then transferred to $10 \mathrm{ml}$ volumetric flasks and diluted to final volume with mobile phase $[4,20]$.

Photo stability: Methanolic stock solutions of Irbesartan, Losartan potassium, Telmisartan, and Valsartan respectively $(10 \mathrm{ml})$ were exposed to light providing an overall illumination of not less than 1.2 million lux hours and an integrated near ultraviolet energy of not less than 200 watt hours/square meter. Also the experiment was performed on solid-state samples which could be stressed under previous condition and then diluted with a known amount of mobile phase. The solutions $(1 \mathrm{ml})$ obtained were then transferred to $10 \mathrm{ml}$ volumetric flasks and diluted to final volume with mobile phase $[4,22]$.

Stress-testing conditions: According to $\mathrm{ICH}$ recommendations at least five conditions must be used. In this study the Conditions were chosen as Solid, Aqueous solution, $0.1 \mathrm{~N} \mathrm{HCl}$ solution, Aqueous Solution, $0.1 \mathrm{~N} \mathrm{NaoH}$ solution, $0.3 \% \mathrm{H}_{2} \mathrm{O}_{2}$ solution (Table 1) [20].

\section{Method Validation}

\section{Specificity}

The Specificity of the method was evaluated by assessing whether

\begin{tabular}{|l|l|l|}
\hline Sample condition & Storage condition & Time points for a detailed study \\
\hline Solid & $70^{\circ} \mathrm{C}$ & $7,14,28$ days \\
\hline Solid & simulated sunlight & Exposure $2-3$ times ICH guideline \\
\hline Aqueous solution & simulated sunlight & Exposure $1-3$ times ICH guideline \\
\hline $\mathbf{0 . 1} \mathbf{N ~ H C l}$ solution & up to $70^{\circ} \mathbf{C}$ & $3,7,14$ days \\
\hline Aqueous Solution & up to $70^{\circ} \mathrm{C}$ & $3,7,14$ days \\
\hline $\mathbf{0 . 1} \mathbf{N ~ N a O H}$ solution & up to $70^{\circ} \mathrm{C}$ & $3,7,14$ days \\
\hline $\mathbf{0 . 3} \% \mathbf{H}_{\mathbf{2}} \mathbf{O}_{\mathbf{2}}$ solution & up to $70^{\circ} \mathrm{C}$ & 3,7 days \\
\hline
\end{tabular}

Table 1: Proposed storage conditions and time points for a detailed study (solidstate stress).

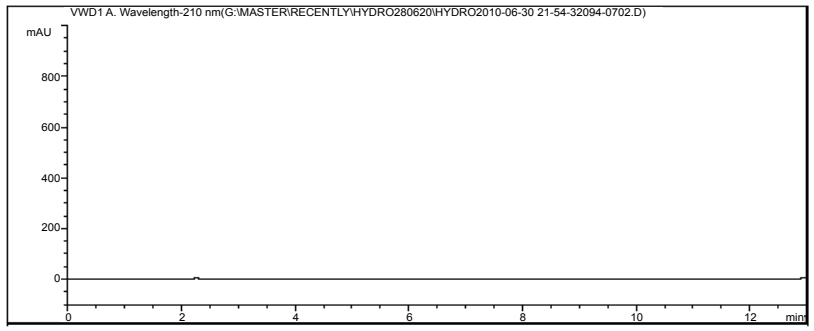

a- tablet placebo under optimized chromatographic conditions
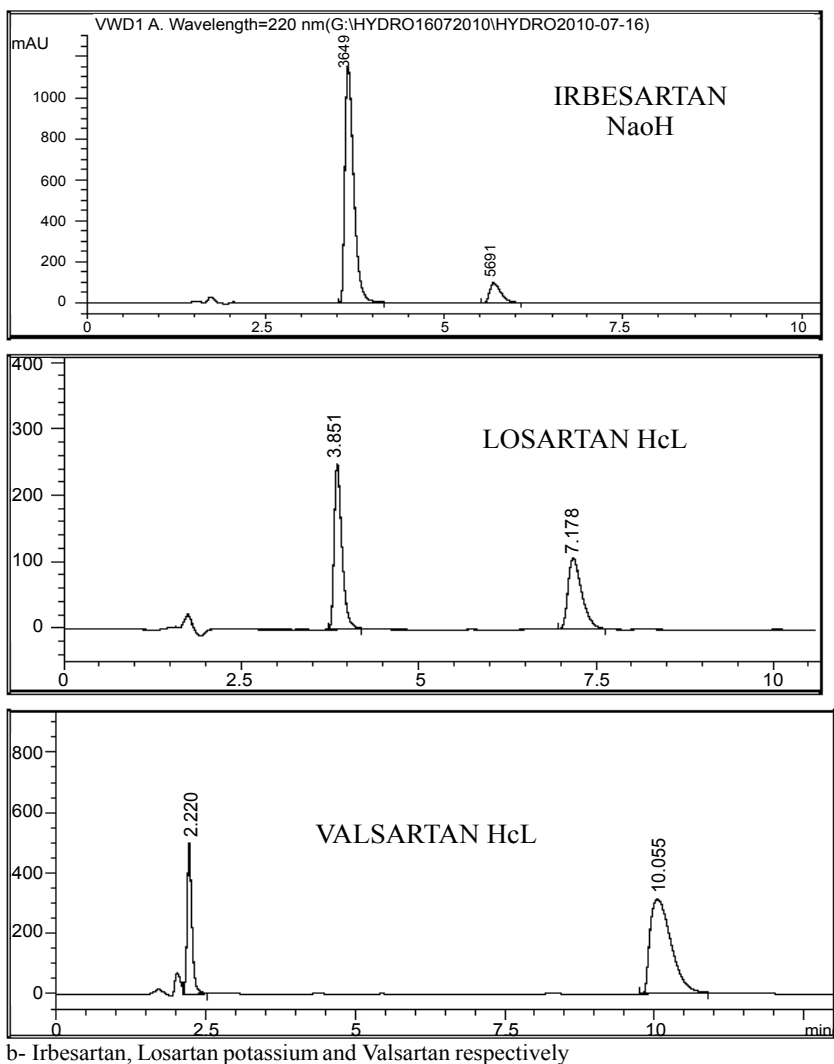

Figure 3: Typical HPLC chromatograms obtained from $50 \mu \mathrm{l}$ injections of Irbesartan, Losartan potassium and Valsartan respectively are obtained from stress studies involving acid, base as well as analysis of samples stored under $\mathrm{ICH}$ stability conditions under optimized chromatographic conditions isocratic method. 
excipients present in the pharmaceutical formulations interfered with the analysis [23]. A placebo for each tablet was prepared by mixing the respective excipients. Solutions were prepared by following the procedure described in the section on sample preparation. The commonly used tablet excipients did not interfere with the method. The diluent chromatogram shows that the tablet diluent has negligible contribution after the void volume at the method detection wavelength of $220 \mathrm{~nm}$. The method were also evaluated by assessing whether degradation products present in the pharmaceutical formulations interfered with the analysis, obtained from stress studies involving acid, base, peroxide, and heat as well as analysis of samples stored under ICH stability conditions (Figure 3 ).

\section{Linearity and range}

According to ICH recommendations [Q2R1] [21], at least five concentrations must be used. In this study five concentrations were chosen in the ranges $(30-180,10-60,16-96$, and $16-96 \mu \mathrm{l} / \mathrm{ml})$ corresponding levels of $20-120 \% \mathrm{w} / \mathrm{w}$ of the nominal analytical concentration for Irbesartan, Losartan potassium, Telmisartan and Valsartan respectively. The linearity of peak area responses versus concentrations was demonstrated by linear least square regression analysis. The linear regression equations were $\{\mathrm{Y}=116.98 \mathrm{X}+198.75$ $(\mathrm{r}=1.0), \quad \mathrm{Y}=133.95 \mathrm{X}+68.63 \quad(\mathrm{r}=1.0), \quad \mathrm{Y}=193.2 \mathrm{X}+550.8 \quad(\mathrm{r}=0.9997)$, $\mathrm{Y}=113.1 \mathrm{X}+222.2 \quad(\mathrm{r}=0.9998)\}$ for Irbesartan, Losartan potassium, Telmisartan and Valsartan respectively. Where $\mathrm{Y}$ is the peak area of standard solution and $\mathrm{X}$ is the drug concentration.

\section{Precision}

The precision of the method was investigated by measurement of both repeatability and Intermediate precision [21].

Repeatability: Repeatability is also termed intra-assay precision. Repeatability was investigated by injecting 6 determinations at $100 \%$ of the test concentration. RSD were calculated (Table 2).

Intermediate precision: In the inter-day studies, standard and sample solutions prepared as described above, were analyzed in triplicate on three consecutive days at $100 \%$ of the test concentration. RSD were calculated (Table 3 ).

\section{Accuracy}

Accuracy was assessed using 9 determinations over 3 concentration levels covering the specified range (80,100 and120\%). Accuracy was reported as percent recovery by the assay of known added amount of analyte in the sample (Table 4 ).

\section{Limits of detection and Limits of quantitation}

In accordance with ICH recommendations [21], determination of limits of detection and quantitation was based on the standard deviation of the $y$-intercepts of regression lines $(n=3)$ and the slope of the calibration plots. The values obtained are given in table 5 .

\section{Robustness}

Robustness of an analytical procedure is a measure of its capacity to remain unaffected by small deliberate variations in method parameters and provides an indication of its reliability during normal usage. Robustness was assessed by studying the effect of changing mobile phase $\mathrm{pH}$ by \pm 0.1 , the amount of acetonitrile in the mobile phase by \pm $2 \%$, temperature $\pm 2{ }^{\circ} \mathrm{C}$, different column and flow rate $\pm 0.05 \mathrm{ml} / \mathrm{min}$. Variations had no significant effect on the chromatographic resolution of the method.

\section{Stability of analytical solution}

Also as part of evaluation of robustness, Solution stability was evaluated by monitoring the peak area response. Standard solutions in methanol were analyzed after its preparation 1,2 and 3 days after at $5^{\circ} \mathrm{C}$ and for a day at room temperature. The change in standard solution peak area response over 3 days was $(0.56,0.74,0.53$ and $0.97 \%)$ for Irbesartan, Losartan potassium, Telmisartan and Valsartan respectively and no significant degradation was observed during this period. Their solutions were found to be stable for 3 days at $5^{\circ} \mathrm{C}$ (in the refrigerator) and for a day at room temperature at least.

\section{Application on pharmaceutical Preparation}

The proposed methods were successfully used to determine Irbesartan, Losartan potassium, Telmisartan and Valsartan respectively in their dosage forms e.g. X-tension tablets, LosarMepha tablets, Micardis tablets and Disartan capsules respectively.

\begin{tabular}{|l|l|l|l|}
\hline Drug name & Average $\boldsymbol{\mu g} / \mathbf{m l}$ & Average $\%$ & RSD \\
\hline Irbesartan & 150.06 & 100.04 & $0.17 \%$ \\
\hline Losartan potassium & 49.97 & 99.94 & $0.16 \%$ \\
\hline Telmisartan & 80.16 & 100.20 & $0.15 \%$ \\
\hline Valsartan & 79.96 & 99.95 & $0.13 \%$ \\
\hline
\end{tabular}

Table 2: Repeatability of Irbesartan, Losartan potassium, Telmisartan and Valsartan respectively.

\begin{tabular}{|l|l|l|l|l|l|l|}
\hline Drug name & $\begin{array}{l}\mathbf{1}^{\text {st }} \text { day } \\
\mathbf{\mu g} / \mathbf{m l}\end{array}$ & $\begin{array}{l}\mathbf{2}^{\text {nd }} \mathbf{d a y} \\
\mathbf{\mu g} / \mathbf{m l}\end{array}$ & $\begin{array}{l}\mathbf{3}^{\text {rd }} \text { day } \\
\boldsymbol{\mu g} / \mathbf{m l}\end{array}$ & $\begin{array}{l}\text { Pooled } \\
\text { average }\end{array}$ & $\begin{array}{l}\text { Pooled } \\
\text { average } \%\end{array}$ & RSD \\
\hline Irbesartan & 150.06 & 151.83 & 150.48 & 150.79 & 100.52 & $0.61 \%$ \\
\hline $\begin{array}{l}\text { Losartan } \\
\text { potassium }\end{array}$ & 49.97 & 50.78 & 50.18 & 50.31 & 100.63 & $0.83 \%$ \\
\hline Telmisartan & 80.16 & 81.10 & 80.73 & 80.66 & 100.83 & $0.59 \%$ \\
\hline Valsartan & 79.96 & 81.01 & 79.67 & 80.21 & 100.26 & $0.88 \%$ \\
\hline
\end{tabular}

Table 3: Intermediate precision of Irbesartan, Losartan potassium, Telmisartan and Valsartan respectively.

\begin{tabular}{|l|l|l|l|l|l|}
\hline Drug name & $\begin{array}{l}\text { Recovery at } \\
\mathbf{8 0} \% \text { conc. } \\
(\mathbf{\%})\end{array}$ & $\begin{array}{l}\text { Recovery at } \\
\mathbf{1 0 0 \%} \text { conc. } \\
(\mathbf{\%})\end{array}$ & $\begin{array}{l}\text { Recovery at } \\
\mathbf{1 2 0 \%} \text { conc. } \\
\mathbf{( \% )}\end{array}$ & $\begin{array}{l}\text { Average } \\
\text { Recovery } \\
\mathbf{( \% )}\end{array}$ & RSD \\
\hline Irbesartan & 100.9 & 101.3 & 100.21 & 100.8 & $0.55 \%$ \\
\hline $\begin{array}{l}\text { Losartan } \\
\text { potassium }\end{array}$ & 100.88 & 101.65 & 100.35 & 100.96 & $0.65 \%$ \\
\hline Telmisartan & 101.03 & 101.50 & 100.43 & 100.98 & $0.53 \%$ \\
\hline Valsartan & 101.04 & 101.35 & 99.87 & 100.75 & $0.77 \%$ \\
\hline
\end{tabular}

Table 4: Recovery results for standard solution plus excipients fo Hydrochlorothiazide, Irbesartan, Losartan potassium, Telmisartan and Valsartan respectively.

\begin{tabular}{|l|l|l|l|l|}
\hline Item & Irbesartan & Losartan & Telmisartan & Valsartan \\
\hline Linear range $(\mu \mathrm{l} / \mathrm{ml})$ & $30-180$ & $10-60$ & $16-96$ & $16-96$ \\
\hline Detection limit $(\mu \mathrm{g} / \mathrm{ml})$ & 0.007 & 0.06 & 0.01 & 0.13 \\
\hline Quantitation limit $(\mu \mathrm{g} / \mathrm{ml})$ & 0.02 & 0.185 & 0.04 & 0.4 \\
\hline Regression data & & & & \\
\hline $\mathrm{N}$ & 5 & 5 & 5 & 5 \\
\hline Slope $(\mathrm{b})$ & 116.98 & 133.95 & 193.23 & 113.1 \\
\hline $\begin{array}{l}\text { Standard deviation of the } \\
\text { slope }\end{array}$ & 0.06 & 0.02 & 0.22 & 0.15 \\
\hline Intercept $(\mathrm{a})$ & 198.08 & 68.64 & 550.82 & 222.26 \\
\hline $\begin{array}{l}\text { Standard deviation of the } \\
\text { intercept }\end{array}$ & 13.64 & 3.97 & 11.97 & 9.28 \\
\hline Correlation coefficient $(\mathrm{r})$ & 1.0 & 1.0 & 0.9997 & 0.9998 \\
\hline Standard error of regression & 40.1 & 15.25 & 118 & 55.12 \\
\hline
\end{tabular}

Table 5: Calibration data for analysis of the mixture by use of the proposed HPLC method of Irbesartan, Losartan potassium, Telmisartan and Valsartan respectively 
Five replicate determinations were performed. Satisfactory results were obtained for each compound in good agreement with label claims (Table 6 and 7). The results obtained were compared statistically with those from published methods [15,23-25] by using Student's t-test (for accuracy) and the variance ratio F-test (for precision). The results in (Table 8 ) showed that the $\mathrm{t}$ and $\mathrm{F}$ values were smaller than the critical values. So, there were no significant differences between the results obtained from this method and published methods.

\section{Results and Discussion}

\section{Optimization of parameters of HPLC method}

To establish and validate an accurate method for analysis of these drugs in pharmaceutical formulations, preliminary tests were performed with the objective of selecting optimum conditions. The main problems encountered during these investigations were lack of resolution between of Irbesartan and Valsartan and excessive retention of Telmisartan. To solve these problems, ACE column $(25 \mathrm{~cm})$, Hypersil C18 $(15 \mathrm{~cm})$, Hypersil cyano $(\mathrm{CN})$ and Hypersil CPS columns were tried for simultaneous determination of the drugs.

The effect of mobile phase composition were also studied (a) aqueous phase e.g. ammonium acetate buffer, citrate buffer and phosphate buffer (b) organic modifier e.g. acetonitrile and methanol (c) $\mathrm{pH}$ of aqueous phase e.g. 2.5, 3.5, 4.5, 6.0.

Changing $\mathrm{pH}$ of mobile phase from 3.5 to 6.0 affects on eluting of Valsartan because It is ionizable compound containing carboxylic group $(\mathrm{COOH}), \mathrm{pH}$ of mobile phase greater than $\mathrm{pKa}$ of Valsartan (4.9) by more one unit and at $\mathrm{pH}$ 's above the $\mathrm{pKa}$ of the analyte, the acidic analyte carries a negative charge and behaves as an extremely polar molecule [26].

The optimum wavelength for detection was $220 \mathrm{~nm}$ at which much better detector responses for four drugs were obtained. The best resolution with reasonable retention time was obtained at $65 \%$ phosphate buffer $\mathrm{pH} 6.0$ and $35 \%$ acetonitrile as organic modifier. A major reason for using a concentration of $25 \mathrm{mM}$ was achieving maximum sensitivity of UV detection at low wavelengths.

\section{Optimization of parameters of stability indicating method}

According to current good manufacturing practice (cGMP), all drugs must be tested under a stability-indicating method before release. Stress testing of drug substance can help in identifying the likely degradation products which can establish the degradation pathways and the intrinsic stability of the molecule. The nature of the stress testing will depend on the individual drug substance. These studies provide valuable information on drugs inherent stability and help in the validation of analytical methods to be used in stability studies. Because of the special nature of separation requirement during analysis of stability samples, chromatographic methods have taken precedence over the conventional methods of analysis. Other than separation of multiple components, the merits of chromatographic methods are that possess greater accuracy and sensitivity for even small quantities of degradation products produced $[4,20]$.

Degradation studies: The chromatograms obtained from samples treated with acid, base, hydrogen peroxide, heat and photo degradation were examined. The chromatograms showed that both Losartan potassium and Valsartan were degradated under acidic conditions (Figure 4 and 5). Irbesartan also was degradated to large extent under basic conditions (Figure 6) unlike Telmisartan wasn't degradated under all previous condition (Figure 7). In this study, thermal degradation had no effect and acidic and alkaline degradation had some extent effect but if acidic and alkaline degradation undergoes under effect of heat at $70^{\circ} \mathrm{C}$, the extent of degradation increased for Valsartan, Losartan and Irbesartan (Figure 8-10).

The ratio of degradation of Losartan potassium, Valsartan and Irbesartan respectively had been calculated by normalization method (The percentage content of a component of the substance to be examined is calculated by determining the area of the corresponding peak as a percentage of the total area of all the peaks, excluding those due to solvents or reagents or arising from the mobile phase or the sample matrix and those at or below the disregard limit) [5] (Table 9).

Losartan potassium was degradated by acidic hydrolysis $(1 \mathrm{M} \mathrm{HCl}$ at $70^{\circ} \mathrm{C}$ ) to give impurity $\mathrm{E}$ and $\mathrm{F}[12]$. The impurity $\mathrm{E}$ was the major. It was found that many compounds will undergo dimerization reactions: those containing olefins, alcohols, and carboxylic acids (or other carbonyl chemistry e.g. aldol condensation reactions). Indoles have been shown to dimerize under acidic conditions. The dimerization is presumed to occur via protonation and nucleophilic attack of a second indole (Figure 11).

Impurity $\mathrm{E}$ is $\left(\left(-\left(1^{\prime}-[1-[[2-\right.\right.\right.$ butyl-4-chloro-1-[[2' [2-butyl-1-[[2Htetrazol-5-yl)biphenyl-4-yl]methyl]-1H-imidazol-5-yl]methyl]-1Htetrazol-5-yl]biphenyl-4-yl]methyl]-4-chloro-1H-imidazol-5-yl]

\begin{tabular}{|l|l|l|l|l|}
\hline Drug name & Irbesartan (\%) & Losartan (\%) & Telmisartan (\%) & Valsartan (\%) \\
\hline Test 1 & 97.97 & 99.52 & 98.58 & 98.85 \\
\hline Test 2 & 99.99 & 99.96 & 99.18 & 98.59 \\
\hline Test 3 & 99.52 & 100.3 & 101.6 & 99.14 \\
\hline Test 4 & 99.38 & 100.8 & 102.1 & 98.7 \\
\hline Test 5 & 99.45 & 101.1 & 101.8 & 99.63 \\
\hline SD & 0.76 & 0.63 & 1.64 & 0.42 \\
\hline Average & 99.26 & 100.33 & 100.65 & 98.98 \\
\hline R.S.D & 0.77 & 0.63 & 1.63 & 0.42 \\
\hline
\end{tabular}

Table 6: Results from determination of Irbesartan, Losartan potassium, Telmisartan and Valsartan respectively in their dosage forms by proposed method.

\begin{tabular}{|l|l|l|l|l|}
\hline Drug name & Irbesartan (\%) & Losartan (\%) & Telmisartan (\%) & Valsartan (\%) \\
\hline Test 1 & 97.04 & 99.82 & 98.54 & 99.94 \\
\hline Test 2 & 99.44 & 99.73 & 99.06 & 99.63 \\
\hline Test 3 & 99.49 & 99.99 & 98.4 & 100.6 \\
\hline Test 4 & 99.28 & 99.97 & 101.2 & 99.89 \\
\hline Test 5 & 99.67 & 100.8 & 101.2 & 98.89 \\
\hline SD & 1.1 & 0.43 & 1.41 & 0.62 \\
\hline Average & 98.98 & 100.06 & 99.68 & 99.79 \\
\hline R.S.D & 1.1 & 0.43 & 1.41 & 0.61 \\
\hline Method number & 15 & 23 & 24 & 25 \\
\hline
\end{tabular}

Table 7: Results from determination of Irbesartan, Losartan potassium, Telmisartan and Valsartan respectively in their dosage forms by reported method.

\begin{tabular}{|c|c|c|c|c|}
\hline \multirow[b]{2}{*}{ Drug name } & \multicolumn{2}{|c|}{ Recovery \pm SD } & \multirow[b]{2}{*}{$\begin{array}{l}\text { Calculated } \\
\text { t-values }\end{array}$} & \multirow[b]{2}{*}{$\begin{array}{l}\text { Calculated } \\
\text { F-values }\end{array}$} \\
\hline & $\begin{array}{l}\text { Proposed } \\
\text { methods }\end{array}$ & $\begin{array}{l}\text { Reference } \\
\text { method }\end{array}$ & & \\
\hline Irbesartan (\%) & $99.26 \pm 0.76$ & $98.98 \pm 1.10$ & $1.36^{(2.57)}$ & $0.48^{(5.05)}$ \\
\hline Losartan (\%) & $100.33 \pm 0.63$ & $100.06 \pm 0.43$ & $1.53^{(2.57)}$ & $2.21^{(5.05)}$ \\
\hline Telmisartan (\%) & $100.65 \pm 1.64$ & $99.68 \pm 1.41$ & $1.68^{(2.57)}$ & $1.36^{(5.05)}$ \\
\hline Valsartan (\%) & $98.98 \pm 0.42$ & $99.79 \pm 0.62$ & $2.05^{(2.57)}$ & $0.46^{(5.05)}$ \\
\hline
\end{tabular}

(Where the Tabulated t-values and F-ratios at $p=0.05$ are 2.57 and 5.05)

Table 8: Statistical comparison of the proposed and published methods for determination of Irbesartan, Losartan potassium, Telmisartan and Valsartan respectively in their dosage forms by reported method (T-student test) and (F-test for variance). 

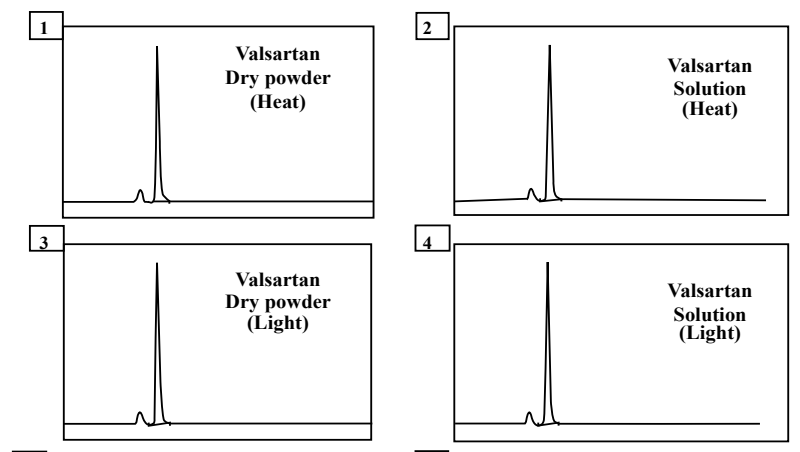

\section{5}

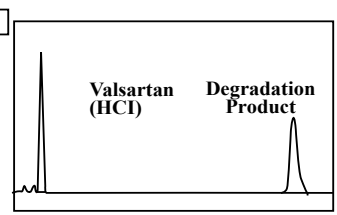

7

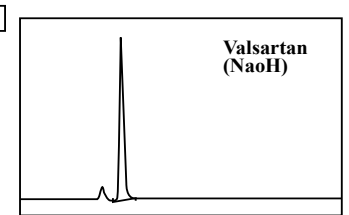

Figure 4: Typical HPLC chromatograms obtained from Valsartan under stress conditions:

1- Dry powder under heat. 2- Methanolic solution under heat.

3- Dry powder under light. $\quad 4$ - Methanolic solution under light.

5- Methanolic solution under $1.0 \mathrm{M} \mathrm{HCl}$ at $70^{\circ} \mathrm{C}$

6- Methanolic solution under $3.0 \% \mathrm{H}_{2} \mathrm{O}_{2}$ at $25^{\circ} \mathrm{C}$.

7- Methanolic solution under $1.0 \mathrm{M} \mathrm{NaOH}$ at $70^{\circ} \mathrm{C}$.
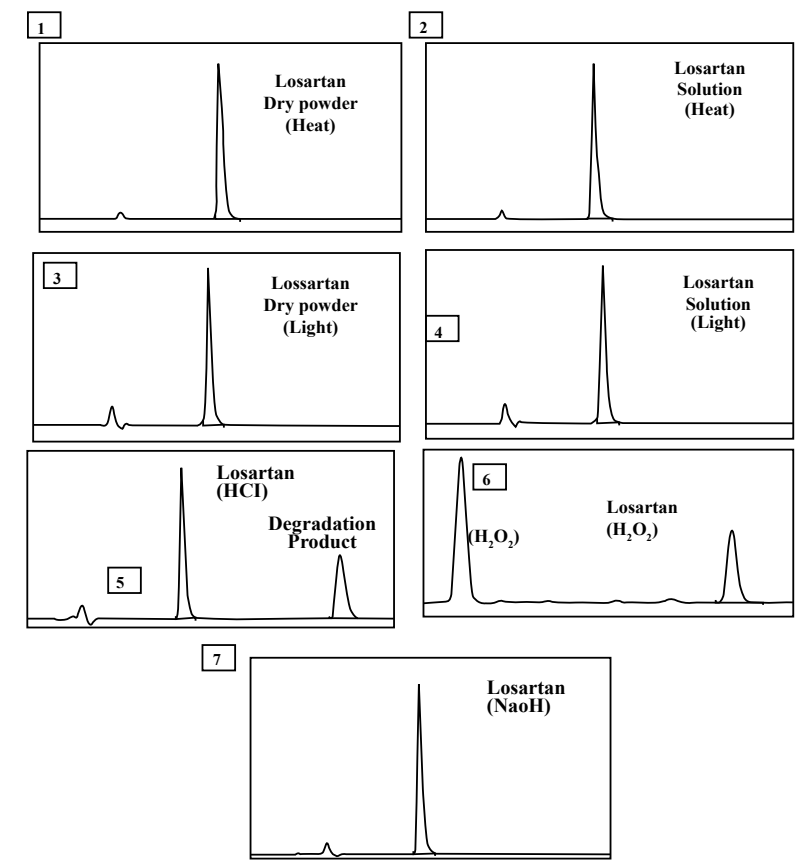

Figure 5: Typical HPLC chromatograms obtained from Losartan under stress conditions:

1- Dry powder under heat. 2- Methanolic solution under heat.

3- Dry powder under light. 4- Methanolic solution under light.

5- Methanolic solution under $1.0 \mathrm{M} \mathrm{HCl}$ at $70^{\circ} \mathrm{C}$.

6- Methanolic solution under $3.0 \% \mathrm{H}_{2} \mathrm{O}_{2}$ at $25^{\circ} \mathrm{C}$.

7- Methanolic solution under $1.0 \mathrm{M} \mathrm{NaOH}$ at $70^{\circ} \mathrm{C}$
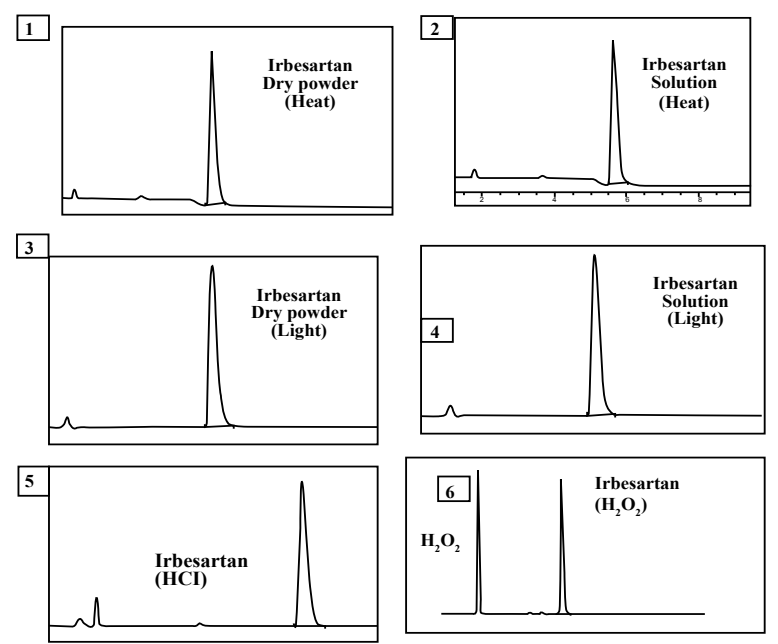

7

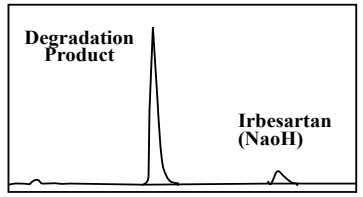

Figure 6: Typical HPLC chromatograms obtained from Irbesartan under stress conditions:

1- Dry powder under heat. 2- Methanolic solution under heat.

3- Dry powder under light. 4- Methanolic solution under light.

5- Methanolic solution under $1.0 \mathrm{M} \mathrm{HCl}$ at $70^{\circ} \mathrm{C}$

6- Methanolic solution under $3.0 \% \mathrm{H}_{2} \mathrm{O}_{2}$ at $25^{\circ} \mathrm{C}$.

7- Methanolic solution under $1.0 \mathrm{M} \mathrm{NaOH}$ at $70^{\circ} \mathrm{C}$
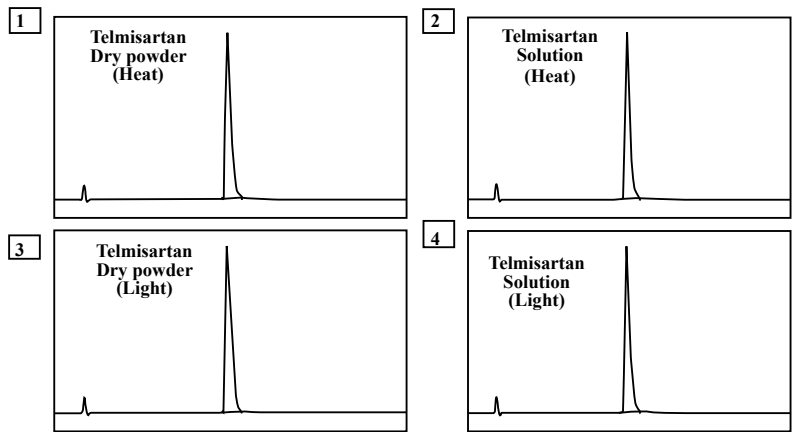

5
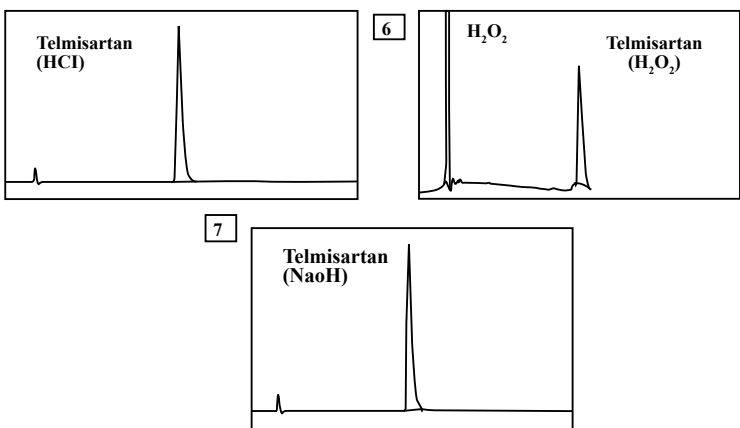

Figure 7: Typical HPLC chromatograms obtained from Telmisartan under stress conditions:

1- Dry powder under heat. 2- Methanolic solution under heat.

3- Dry powder under light. 4- Methanolic solution under light.

5- Methanolic solution under $1.0 \mathrm{M} \mathrm{HCl}$ at $70^{\circ} \mathrm{C}$.

6- Methanolic solution under $3.0 \% \mathrm{H}_{2} \mathrm{O}_{2}$ at $25^{\circ} \mathrm{C}$.

7- Methanolic solution under $1.0 \mathrm{M} \mathrm{NaOH}$ at $70^{\circ} \mathrm{C}$. 

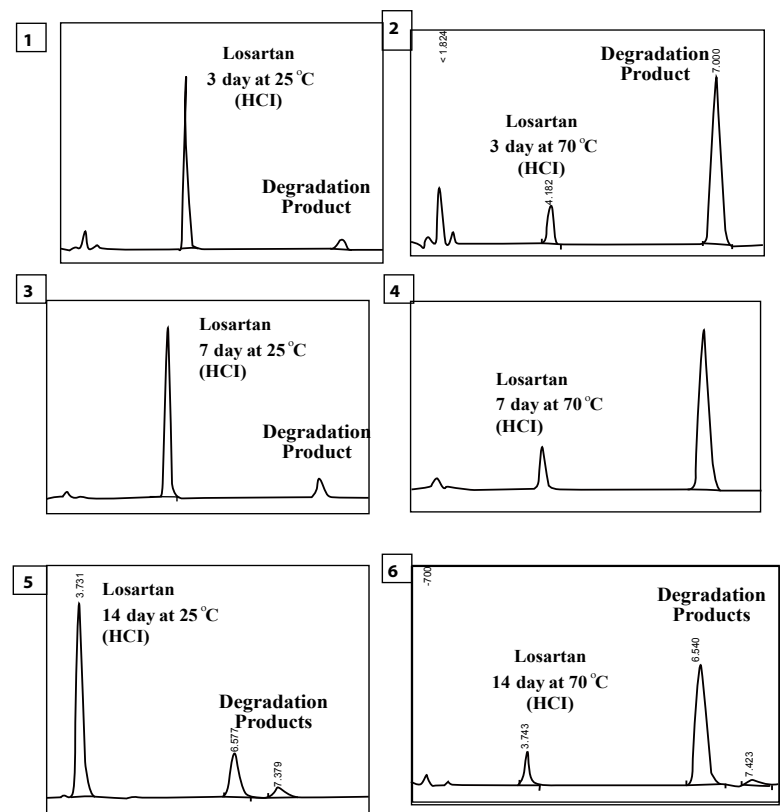

Figure 8: Typical HPLC chromatograms obtained from Losartan under acidic stress conditions:

1- Methanolic solution under $1.0 \mathrm{M} \mathrm{HCl}$ at $25^{\circ} \mathrm{C}$ after 3 days.

2- Methanolic solution under $1.0 \mathrm{M} \mathrm{HCl}$ at $70^{\circ} \mathrm{C}$ after 3 days.

3- Methanolic solution under $1.0 \mathrm{M} \mathrm{HCl}$ at $25^{\circ} \mathrm{C}$ after 7 days.

4- Methanolic solution under $1.0 \mathrm{M} \mathrm{HCl}$ at $70^{\circ} \mathrm{C}$ after 7 days.

5- Methanolic solution under $1.0 \mathrm{M} \mathrm{HCl}$ at $25^{\circ} \mathrm{C}$ after 14 days

6- Methanolic solution under $1.0 \mathrm{M} \mathrm{HCl}$ at $70^{\circ} \mathrm{C}$ after 14 days.
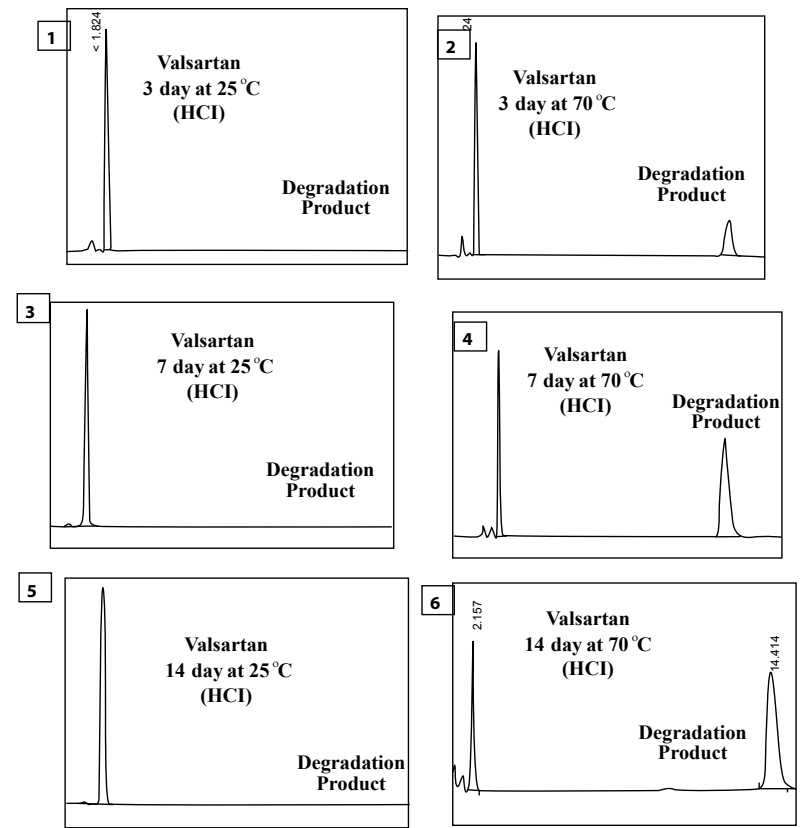

Figure 9: Typical HPLC chromatograms obtained from Valsartan under acidic stress conditions:

1- Methanolic solution under $1.0 \mathrm{M} \mathrm{HCl}$ at $25^{\circ} \mathrm{C}$ after 3 days.

2- Methanolic solution under $1.0 \mathrm{M} \mathrm{HCl}$ at $70^{\circ} \mathrm{C}$ after 3 days.

3- Methanolic solution under $1.0 \mathrm{M} \mathrm{HCl}$ at $25^{\circ} \mathrm{C}$ after 7 days.

4- Methanolic solution under $1.0 \mathrm{M} \mathrm{HCl}$ at $70^{\circ} \mathrm{C}$ after 7 days.

5- Methanolic solution under $1.0 \mathrm{M} \mathrm{HCl}$ at $25^{\circ} \mathrm{C}$ after 14 days.

6- Methanolic solution under $1.0 \mathrm{M} \mathrm{HCl}$ at $70^{\circ} \mathrm{C}$ after 14 days.
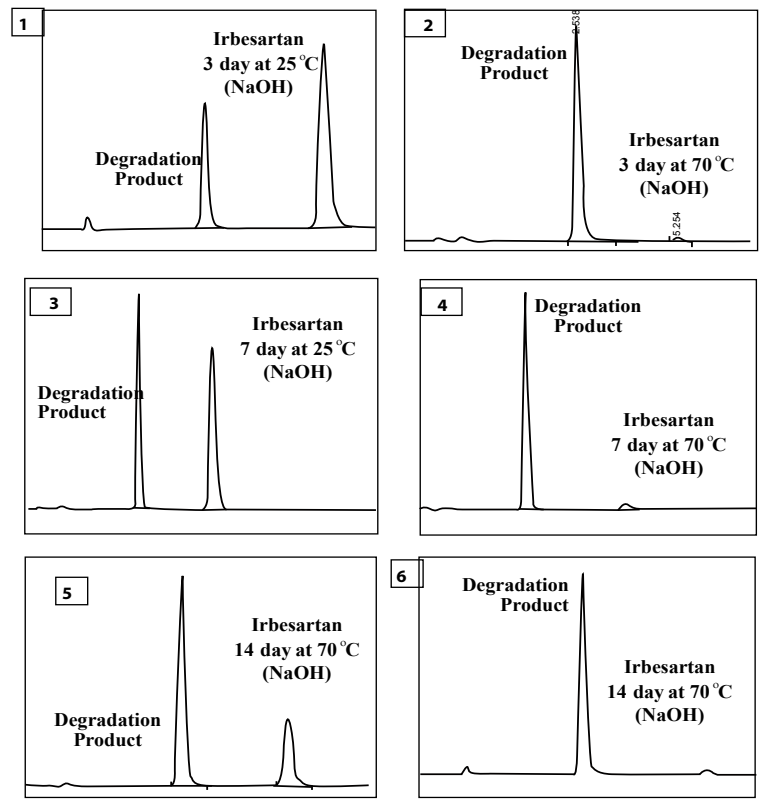

Figure 10: Typical HPLC chromatograms obtained from Irbesartan unde stress alkaline conditions:

1-Methanolic solution under $1.0 \mathrm{M} \mathrm{NaOH}$ at $25^{\circ} \mathrm{C}$ after 3 days

2-Methanolic solution under $1.0 \mathrm{M} \mathrm{NaOH}$ at $70^{\circ} \mathrm{C}$ after 3 days.

3-Methanolic solution under $1.0 \mathrm{M} \mathrm{NaOH}$ at $25^{\circ} \mathrm{C}$ after 7 days.

4-Methanolic solution under $1.0 \mathrm{M} \mathrm{NaOH}$ at $70^{\circ} \mathrm{C}$ after 7 days.

5-Methanolic solution under $1.0 \mathrm{M} \mathrm{NaOH}$ at $25^{\circ} \mathrm{C}$ after 14 days

6-Methanolic solution under $1.0 \mathrm{M} \mathrm{NaOH}$ at $70^{\circ} \mathrm{C}$ after 14 days.

\begin{tabular}{|c|c|c|c|c|c|}
\hline $\begin{array}{l}\text { Losartan } \\
\text { potassium }\end{array}$ & $\begin{array}{l}\text { Principle } \\
\text { peak }\end{array}$ & $\begin{array}{l}\text { Degradation } \\
\text { peak }\end{array}$ & $\begin{array}{l}\text { Sum of } \\
\text { peak }\end{array}$ & $\begin{array}{l}\text { Principle } \\
\text { peak \% }\end{array}$ & $\begin{array}{l}\text { Degradation } \\
\text { peak } \%\end{array}$ \\
\hline 3 days $\left(25^{\circ} \mathrm{C}\right)$ & 4801.31 & 483.62 & 5284.93 & 90.85 & 9.151 \\
\hline 3 days $\left(70^{\circ} \mathrm{C}\right)$ & 493.96 & 3597.9 & 4091.86 & 12.07 & 87.93 \\
\hline 7 days $\left(25^{\circ} \mathrm{C}\right)$ & 3028.6 & 538.87 & 3567.47 & 84.89 & 15.11 \\
\hline 7 days $\left(70^{\circ} \mathrm{C}\right)$ & 455.12 & 3228.05 & 3683.17 & 12.36 & 87.64 \\
\hline 14 days $\left(25^{\circ} \mathrm{C}\right)$ & 2765.89 & 1180 & 3945.89 & 70.1 & 29.9 \\
\hline 14 days $\left(70^{\circ} \mathrm{C}\right)$ & 453.8 & 3071 & 3524.8 & 12.87 & 87.13 \\
\hline Valsartan & $\begin{array}{l}\text { Principle } \\
\text { peak }\end{array}$ & $\begin{array}{l}\text { Degradation } \\
\text { peak }\end{array}$ & $\begin{array}{l}\text { Sum of } \\
\text { peak }\end{array}$ & $\begin{array}{l}\text { Principle } \\
\text { peak \% }\end{array}$ & $\begin{array}{l}\text { Degradation } \\
\text { peak } \%\end{array}$ \\
\hline 3 days $\left(25^{\circ} \mathrm{C}\right)$ & 3896.52 & 45.48 & 3942 & 98.85 & 1.154 \\
\hline 3 days $\left(70^{\circ} \mathrm{C}\right)$ & 2282.36 & 1427.87 & 3710.23 & 61.52 & 38.48 \\
\hline 7 days $\left(25^{\circ} \mathrm{C}\right)$ & 4954.97 & 95.73 & 5050.7 & 98.1 & 1.895 \\
\hline 7 days $\left(70^{\circ} \mathrm{C}\right)$ & 1938.32 & 2943.72 & 4882.04 & 39.7 & 60.3 \\
\hline 14 days $\left(25^{\circ} \mathrm{C}\right)$ & 5110.7 & 150 & 5260.7 & 97.15 & 2.851 \\
\hline 14 days $\left(70^{\circ} \mathrm{C}\right)$ & 1176.08 & 3045.26 & 4221.34 & 27.86 & 72.14 \\
\hline Irbesartan & $\begin{array}{l}\text { Principle } \\
\text { peak }\end{array}$ & $\begin{array}{l}\text { Degradation } \\
\text { peak }\end{array}$ & $\begin{array}{l}\text { Sum of } \\
\text { peak }\end{array}$ & $\begin{array}{l}\text { Principle } \\
\text { peak \% }\end{array}$ & $\begin{array}{l}\text { Degradation } \\
\text { peak \% }\end{array}$ \\
\hline 3 days $\left(25^{\circ} \mathrm{C}\right)$ & 6521.5 & 2749.24 & 9270.74 & 70.34 & 29.66 \\
\hline 3 days $\left(70^{\circ} \mathrm{C}\right)$ & 283.69 & 8453.58 & 8737.27 & 3.247 & 96.75 \\
\hline 7 days $\left(25^{\circ} \mathrm{C}\right)$ & 5001.21 & 4289.9 & 9291.11 & 53.83 & 46.17 \\
\hline 7 days $\left(70^{\circ} \mathrm{C}\right)$ & 314.76 & 9286.84 & 9601.6 & 3.278 & 96.72 \\
\hline 14 days $\left(25^{\circ} \mathrm{C}\right)$ & 2751.72 & 6374.8 & 9126.52 & 30.15 & 69.85 \\
\hline 14 days $\left(70^{\circ} \mathrm{C}\right)$ & 169.15 & 9116.94 & 9286.09 & 1.821 & 98.18 \\
\hline
\end{tabular}

Table 9: Percentages of degradation by normalization method for Losartan potassium, Valsartan and Irbesartan respectively.

methanol) )Impurity F is - (1'-[2-[[2-butyl-4-chloro-1-[[2' (( ([2-butyl-1[[2H-tetrazol-5-yl)biphenyl-4-yl]methyl]- $1 H$-imidazol-5-yl]methyl]$2 H$-tetrazol-5-yl]biphenyl-4-yl]methyl]-4-chloro- $1 H$-imidazol-5-yl] methanol)) (Figure 12). 
A-

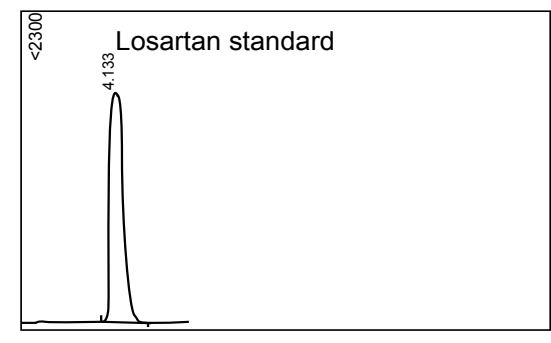

B-

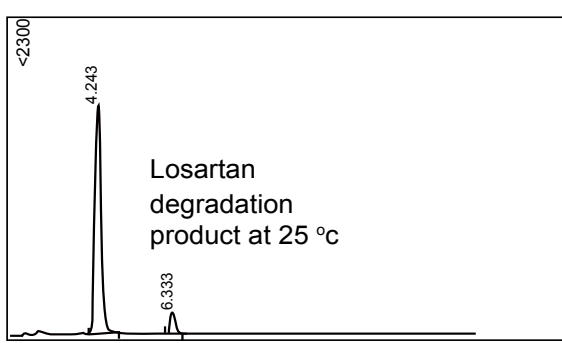

C-

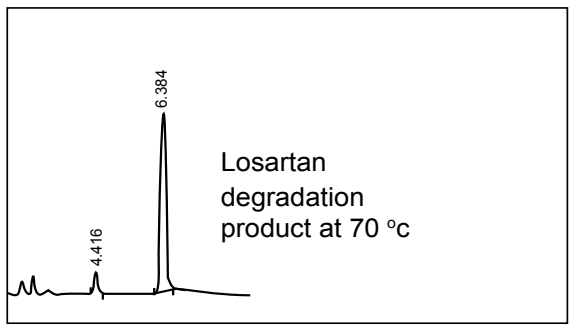

Figure 11: Typical HPLC chromatograms obtained from (a) Losartan standard and $(b, c)$ Losartan under acidic stress conditions $\left(1.0 \mathrm{M} \mathrm{HCl}\right.$ at $\left.70^{\circ} \mathrm{C}\right)$ according to method [12].
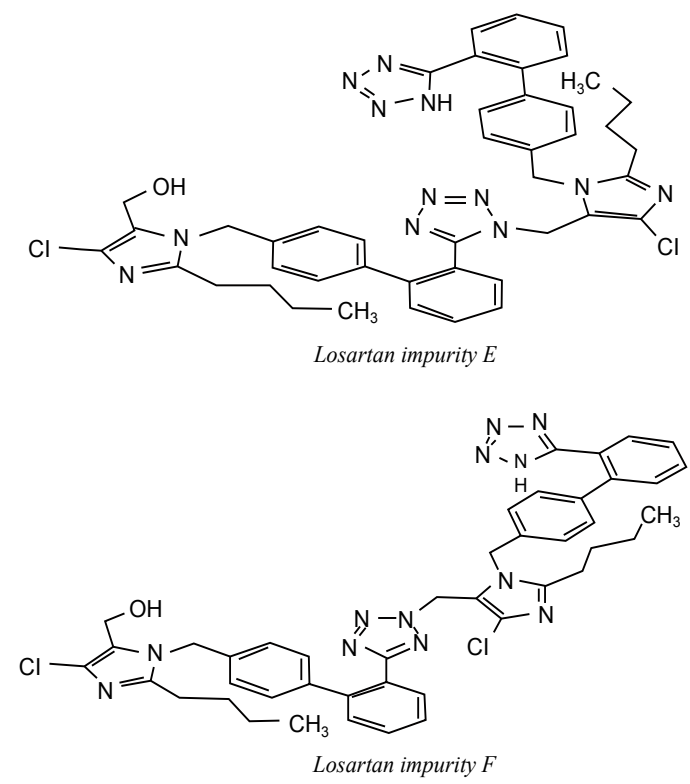

Figure 12: Chemical structure of Losartan impurity $E$ and $F$.
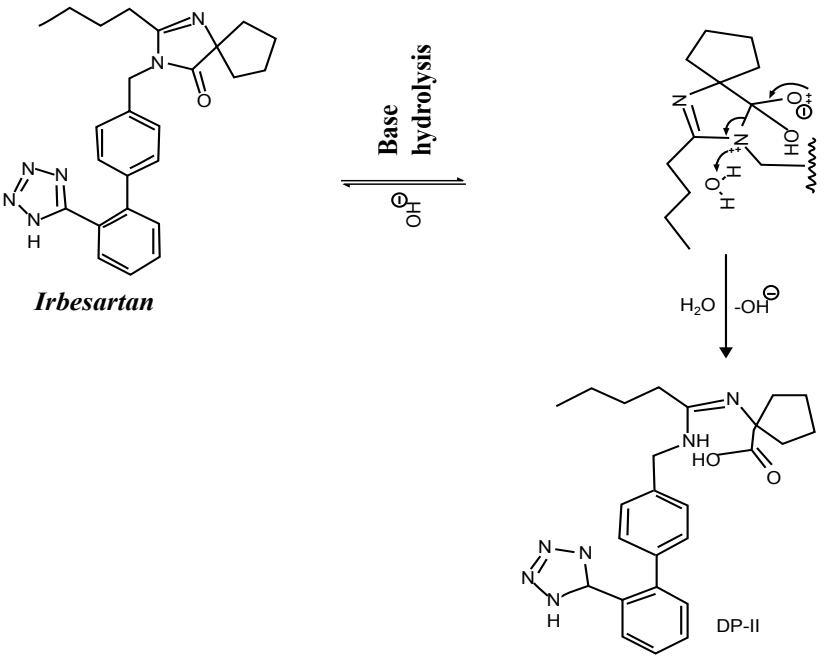

Irbesartan compound $A$

Figure 13: Schematic diagram shows formation of Irbesartan compound A

A-

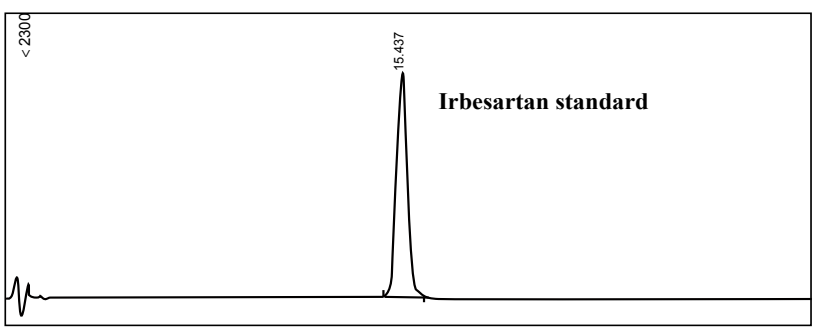

B-

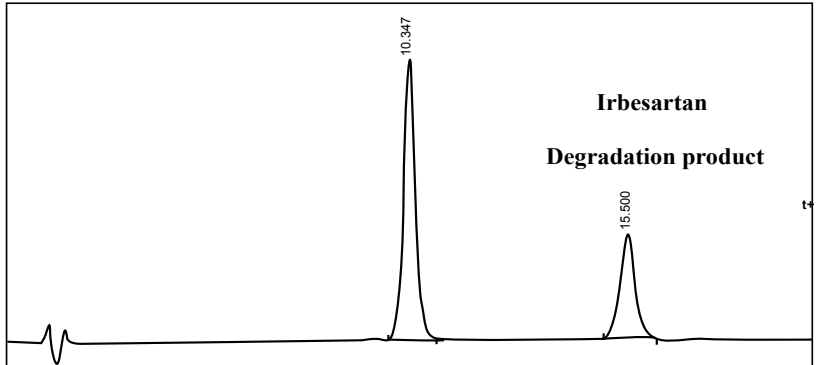

Figure 14: Typical HPLC chromatograms obtained from (a) Irbesartan standard and (b) Irbesartan under alkaline stress conditions (1.0 M NaOH at $25^{\circ} \mathrm{C}$ ) according to USP [5].

Impurity $\mathrm{E}$ and $\mathrm{F}$ are isomer resulting from dimerization of two molecules of Losartan potassium by formation of a bond between nitrogen atom in tetrazole ring and carbon atom in 5- methanol in imidazole ring producing dimer and water.

Irbesartan was degradated by alkaline hydrolysis $(1 \mathrm{M} \mathrm{NaoH}$ at $70^{\circ} \mathrm{C}$ ) to give Irbesartan compound A [5]. It hydrolyzed by rupture of amide link in 1,3-diazaspiro [4.4] non-1-en-4-one. Irbesartan compound A was identified as ((1-(1- $\left(\left(2^{\prime}-(1 \mathrm{H}-\right.\right.$ tetrazol-5- yl $)$ biphenyl4-yl) methyl amino) pentylidene amino) cyclopentane carboxylic acid)) (Figure 13). 

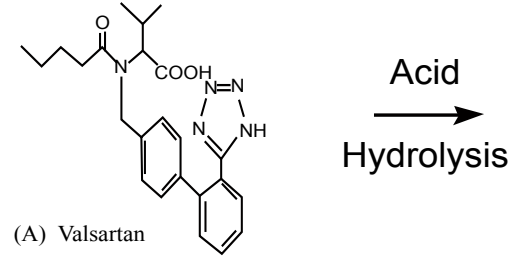

(B) Imp-A
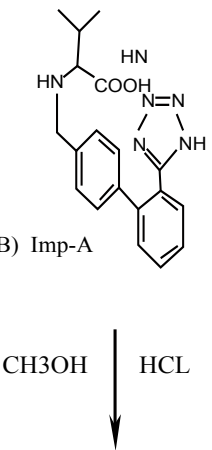

(F) Imp-E

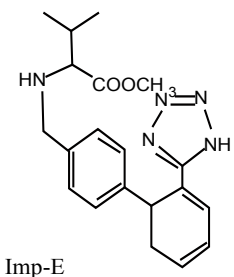

Figure 15: Schematic diagram shows formation of Valsartan related compound.

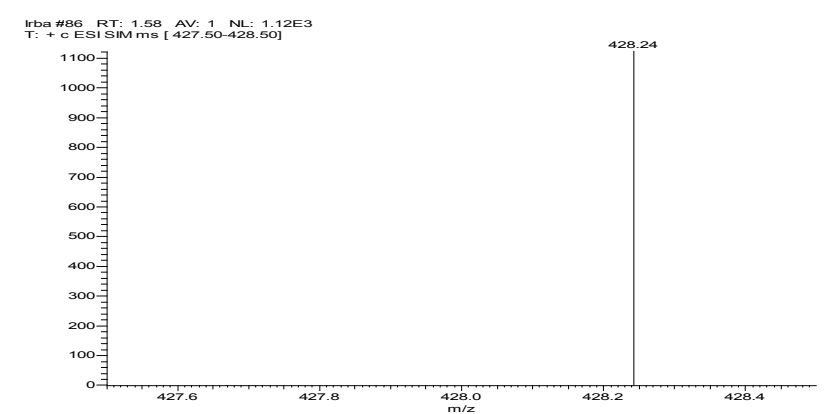

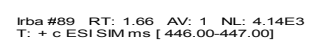

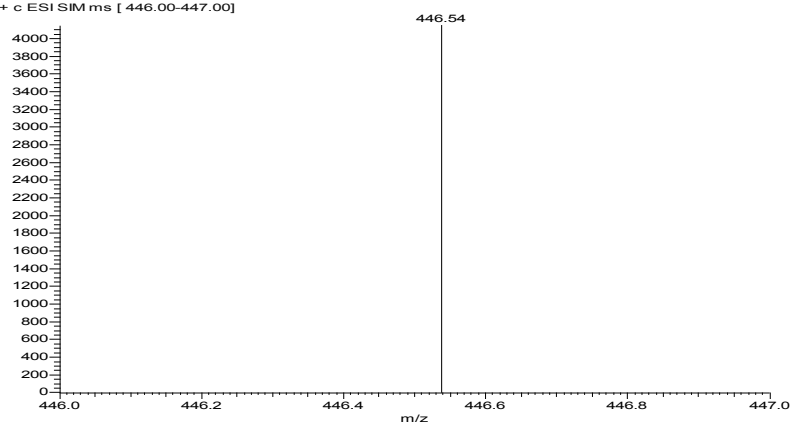

Figure 16: Representative LC-SIM chromatograms for a- Irbesartan at $\mathrm{m} /$ $\mathrm{z}=428 \mathrm{~b}$ - Irbesartan related compound A at $\mathrm{m} / \mathrm{z}=446$ in positive mode.

Valsartan was degraded by acidic hydrolysis $\left(1 \mathrm{M} \mathrm{HCl}\right.$ at $\left.70^{\circ} \mathrm{C}\right)$ to give impurity (E). There is a question, why was impurity $\mathrm{E}$ not impurity A the formed under acidic hydrolysis as degradation product? (Figure14).

It was found that carboxylic acids typically have pKa's in the range of 2-5.5 (depending on the nature of the substituents). Below the $\mathrm{pKa}$ (as in acidic hydrolysis), the carboxylic group is protonated and therefore the carbonyl carbon is more electrophilic. The carbonyl can undergo nucleophilic attack to form esters, amides, thioesters, etc.
In the case of attack by an alcohol, the reaction product is an ester and the reaction is called an esterification reaction. This can occur as an artifact reaction when acid/base hydrolysis reactions are performed using an alcohol co-solvent system such as methanol. Esters of the parent compound can also be observed as process-related impurities especially when alcohol solvents are used in the re-crystallization step.

Above the $\mathrm{pKa}$, the carboxylate is anionic and the charge is resonance stabilized; the group is therefore less electrophilic and does not have a good leaving group. Therefore, reactions with nucleophiles are significantly suppressed when compared to the protonated form. Carboxylic acids are not prone to oxidative degradation (Figure 15).

For more investigation, samples containing related compound of
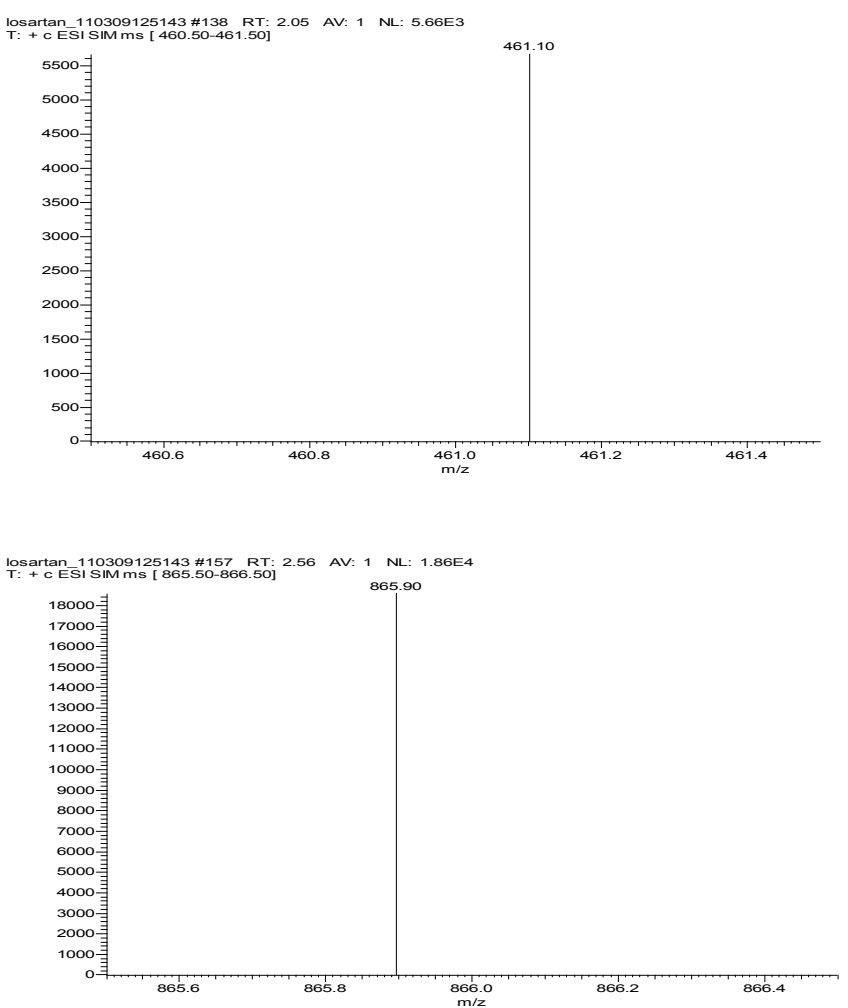

Figure 17: Representative LC-SIM chromatograms for a- Losartan at $\mathrm{m} / \mathrm{z}$ $=461 \mathrm{~b}$ - Losartan related dimer $\mathrm{E}$ at $\mathrm{m} / \mathrm{z}=865$ in positive mode.

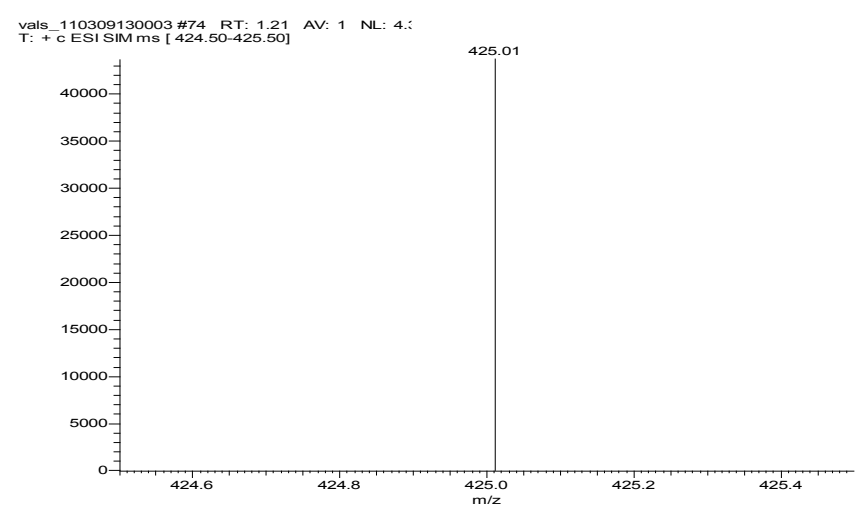

Figure 18: Representative LC-SIM chromatograms for a- Valsartan at $\mathrm{m} /$ $z=425$ in positive mode. 
Citation: Elshanawane AA, Abdelaziz LM, Hafez HM (2012) Stability Indicating HPLC Method for Simultaneous Determination of Several AngiotensinII-Receptor Antagonists in Their Dosage Forms. Pharmaceut Anal Acta 3:175. doi:10.4172/2153-2435.1000175

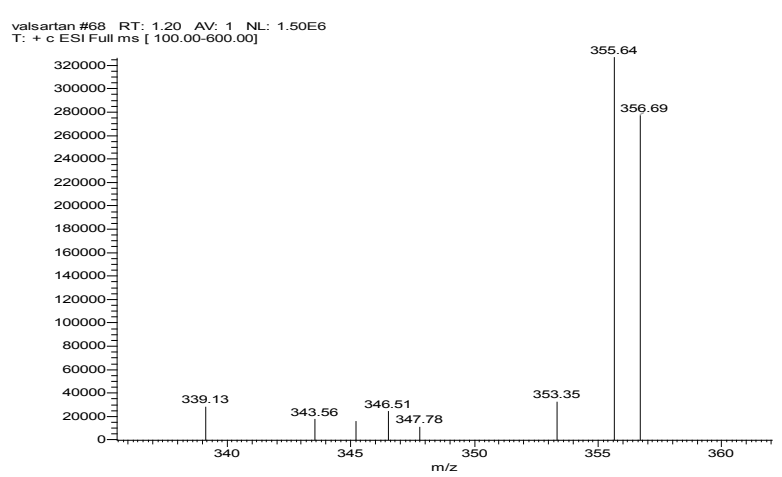

Figure 19: Full-scan product ion mass spectra of $[\mathrm{M}-\mathrm{H}]^{+}$ions of Valsartan related compound $A$ at $\mathrm{m} / \mathrm{z}=355$ in positive mode.

the three drugs subjected to liquid tandem mass analysis by using full scan and selective ion monitoring (SIM) and the results from HPLC method were confirmed by that of LC-MS

A. Irbesartan and its related compound A: (Figure 16)

B. Losartan and its dimers (degradated compound E): (Figure 17)

C. Valsartan and its related compound A: (Figure 18 and 19).

\section{Conclusion}

A simple, rapid, accurate, precise, robust and reliable HPLC method has been established for simultaneous determination and stability indicating HPLC method for Irbesartan, Losartan potassium, Telmisartan and Valsartan either alone, in synthetic mixture or in their formulations. The method has several advantages, including

1. It depends on previous study has been established to reach the optimum stress condition in drug development process and time points for a detailed study (solid-state stress). It is a practical scientific standardized guide for stress condition. (ICH did not explain stress condition in details).

2. Resulting degraded compound elucidated by mass spectroscopy and provided by mechanisms of the reactions.

3. It is the first study for stress condition comprises these four ARA-II compounds together.

4. HPLC with UV detection becomes the most available apparatus and is a low cost instrument in comparison with HPLC coupling with mass spectroscopy and capillary electrophoresis.

5. Rapid analysis (isocratic elution), simple sample preparation, does not use polluting reagents.

6. A simple mobile phase does not affect on column reproducibility (not like ion pair mobile phase)

7. Improved sensitivity LOD and LOQ ranged from (0.007-0.13) - (0.02-0.4) $\mu \mathrm{g} / \mathrm{ml}$.

It is suitable for analysis of antihypertensive agents in their formulations in a single isocratic run, in contrast with previous methods. This makes the method suitable for routine analysis in quality control laboratories.

\section{References}

1. González L, López JA, Alonso RM, Jiménez RM (2002) Fast screening method for the determination of angiotensin II receptor antagonists in human plasma by high-performance liquid chromatography with fluorimetric detection. J Chromatogr A 949: 49-60.

2. Ferreirósa N, Iriartea G, Alonso RM, Jiméneza RM (2007) Development of a solid phase extraction procedure for HPLC-DAD determination of several angiotensin II receptor antagonists in human urine using mixture design. Talanta 73: 748-756.

3. Karen MA, Linda M, Steven WB (2003) A Stress Testing. Benchmarking Study

4. ICH Harmonized Tripartite Guideline (2003) Stability Testing of New Drug Substances and Products Q1A (R2).

5. Health wise Knowledgebase (2011) US Pharmacopoeia, Rockville.

6. British Pharmacopoeia, London (2011) with the monographs of the sixth edition of the European pharmacopoeia monograph.

7. Cagigal E, González L, Alonso RM, Jimenez RM (2001) pK(a) determination of angiotensin II receptor antagonists (ARA II) by spectrofluorimetry. J Pharm Biomed Anal 26: 477-486.

8. Hillaert S, Van den Bossche W (2002) Optimization and validation of a capillary zone electrophoretic method for the analysis of several angiotensin-II-receptor antagonists. J Chromatogr A 979: 323-333.

9. Hillaert S, De Beer TR, De Beer JO, Van den Bossche W (2003) Optimization and validation of a micellar electrokinetic chromatographic method for the analysis of several angiotensin-II-receptor antagonists. J Chromatogr A 984: 135-146.

10. Hertzog DL, McCafferty JF, Fang X, Tyrrell RJ, Reed RA (2007) Development and validation of a stability-indicating HPLC method for the simultaneous determination of losartan potassium, hydrochlorothiazide, and their degradation products. J Pharm Biomed Anal 30: 747-760.

11. McCarthy KE, Wang Q, Tsai EW, Gilbert RE, Brooks MA (2007) Determination of Losartan and its degradates in COZAAR tablets by reversed-phase highperformance thin-layer chromatography. J Pharm Biomed Anal 17: 671-677.

12. Iwasa T, Takano T, Hara K, Kamei T (1999) Method for the simultaneous determination of losartan and its major metabolite, EXP-3174, in human plasma by liquid chromatography-electrospray ionization tandem mass spectrometry. $J$ Chromatogr B Biomed Sci Appl 734: 325-330.

13. Passos Maio VM, Dias CL, Bergold AM (2005) Validation of an isocratic HPLC assay of Losartan Potassium in pharmaceutical formulations and stress test for stability evaluation of drug substance. Acta Farm Bonaerense 24: 250-255.

14. Shah RP, Sahu A, Singh S (2010) Identification and characterization of degradation products of irbesartan using LC-MS/TOF, MS ${ }^{n}$, on-line H/D exchange and LC-NMR. J Pharm Biomed Anal 51: 1037-1046.

15. Rane VP, Patil KR, Sangshetti JN, Yeole RD, Shinde DB (2010) Stability indicating LC method for simultaneous determination of irbesartan and hydrochlorothiazide in pharmaceutical preparations. J Chromatogr Sci 48: 595600

16. Iriarte G, Gonzalez O, Ferreirós N, Magureguia MI, Alonso RM, Jiménez RM (2009) Validation of a fast liquid chromatography-UV method for the analysis of drugs used in combined cardiovascular therapy in human plasma. J Chromatogr B 877: 3045-3053

17. Patro SK, Kanungo SK, Patro VJ, Choudhury NSK (2010) Stability Indicating RP-HPLC Method for Determination of Valsartan in Pure and Pharmaceutical Formulation. E-J Chem 7: 246-252.

18. Krishnaiah Ch, Reddy AR, Kumar R, Mukkanti K (2010) Stability-indicating UPLC method for determination of Valsartan and their degradation products in active pharmaceutical ingredient and pharmaceutical dosage forms. J Pharm Biomed Anal 53: 483-489.

19. Kishore CP, Reddy VB, Kale DM (2010) Development and validation of stability indicating HPLC method for the estimation of telmisartan related substances in tablets formulation. Int J Res Pharm Sci 1: 493-501.

20. Baertschi SW (2005) Pharmaceutical Stress Testing, Predicting Drug Degradation. (1stedn), Taylor \& Francis Group, New York. 
Citation: Elshanawane AA, Abdelaziz LM, Hafez HM (2012) Stability Indicating HPLC Method for Simultaneous Determination of Several AngiotensinII-Receptor Antagonists in Their Dosage Forms. Pharmaceut Anal Acta 3:175. doi:10.4172/2153-2435.1000175

21. ICH Harmonized Tripartite Guideline (1994) Validation of Analytical Procedures: Text and Methodology Q2 (R1).

22. ICH Harmonized Tripartite Guideline (1996) Stability Testing: Photo stability Testing of New Drug Substances and Products Q1B.

23. Hamdy Z, Youssef A (2006) Specification of Losazide tablets (Losartan potassium and hydrochlorothiazide). Egyptian international pharmaceutical industry company, M.O.H. (Egypt) NO: 24522/2006.
24. Wankhede SB, Tajne MR, Gupta KR, Wadodkar SG (2007) RP-HPLC method for simultaneous estimation of telmisartan and hydrochlorothiazide in tablet dosage form. Ind J Pharm Sci 69: 298-300.

25. Satana E, Altınay S, Göger NG, Özkan SA, Sentürk Z (2001) Simultaneous determination of valsartan and hydrochlorothiazide in tablets by first-derivative ultraviolet spectrophotometry and LC. J Pharm Biomed Anal 25: 1009-1013.

26. Preparing Buffered Mobile Phases for Reversed Phase HPLC. 